\title{
Fatherhood after Union Breakup in Uruguay: Transitory or Life-Long Commitment?
}

Journal of Family Issues 2020, Vol. 4I(6) 784-807

(C) The Author(s) 2019

Article reuse guidelines: sagepub.com/journals-permissions DOI: $10.1177 / 0192513 \times 19882960$ journals.sagepub.com/home/jfi

(S)SAGE

\section{Ignacio Pardo' (iD, Teresa Martín-García², \\ Teresa Castro-Martín', and Wanda Cabella*,I}

\begin{abstract}
Rising union dissolution in Latin America-and in much of the worldhas increased public concern over the involvement of nonresidential fathers in the lives of their children. At the same time, social norms about post-separation fatherhood have changed, increasingly favoring not only economic support, but also participation in child-rearing. In this article, we (a) examine several dimensions of nonresidential fathers' involvement with their children, (b) test whether there is a link between pre-separation and post-separation fathering practices, and (c) explore which dimension of pre-separation fathering practices-engagement, accessibility, and responsibility-is more influential on post-separation paternal behavior. The study is based on two waves of a longitudinal national survey carried out in Uruguay. Empirical findings suggest that fathers' pre-separation involvement in child-rearing affects their postseparation parenting behavior, although results are not conclusive in all aspects of post-separation involvement, and father's educational attainment tends to have a more influential role.
\end{abstract}

\footnotetext{
'Universidad de la República, Montevideo, Uruguay

${ }^{2}$ Spanish National Research Council, Madrid, Spain

*Authors have contributed equally to this study.

Corresponding Author:

Ignacio Pardo, Universidad de la República, Constituyente I502 / 4, Montevideo, I I200,

Uruguay.

Email: ignacio.pardo@cienciassociales.edu.uy
} 


\section{Keywords}

Fatherhood, fathering, paternal involvement, separation, nonresidential fathers, childcare, Uruguay

\section{Introduction}

Ever since divorce rates started to increase, family scholars have studied the weakening effect of parental separation ${ }^{1}$ on father-child relationships. High parental separation rates and the extent to which nonresident fathers lose contact with their child(ren) have sparked concern about the negative effects of father absence on children's well-being and life chances (Härkönen, Bernardi, \& Boertien, 2017; McLanahan \& Percheski, 2008; Sigle-Rushton \& McLanahan, 2004). In fact, the steady decline of father-child co-residence among men lends support to claims about "shrinking fatherhood" and "fathers pulling out of family life" (Henz, 2014).

Topics such as the prevalence of father-absent families and the mechanisms that underlie the "parental separation penalty" have been widely researched in more developed countries since the 1980s. Initially, research focused on showing that, after parental union breakup, a significant proportion of children and adolescents lost contact with their fathers and, when they did not, the frequency of visits was highly variable (Amato \& Gilbreth, 1999; Manning \& Smock, 1999; Seltzer \& Bianchi, 1988), suggesting some men's limited attachment to the paternal role after separation (Furstenberg \& Cherlin, 1991; Seltzer, 1991). In recent years, the focus has largely shifted from the frequency of father-child contacts and child support payments to a more comprehensive analysis of the quality and content of nonresident fathers' involvement with their children-including shared activities, communication, emotional closeness, and investments of time and money-after the reconfiguration of residential arrangements caused by the breakup (Choi, Palmer, \& Pyun, 2014). In advanced societies, the nature and meaning of the distant father - traditionally associated with the patriarcal model — has gradually weakened, leading to a new concept of paternity, which entails a more active and emotionally involved fatherhood. Men have gone from being mere economic providers and protectors to adopting a larger and more significant role as caregivers of their offspring. This new fatherhood involves a growing emphasis on nurturing, practical care and co-parenting over the traditional role of the breadwinner (Machin, 2015).

In this study, we focus on union dissolution and fathers' involvement in raising children. We want to understand whether this new, more involved fatherhood also holds after union breakup, and the extent to which post-separation 
paternal involvement reflects pre-separation fathering practices. An overview of the increasing demand from nonresident fathers to spend more time with their children and engage more actively in cooperative parenting is followed by a description of the context in which the study takes place and our research questions, highlighting the importance of early parenting experiences and the development of a "positive paternal involvement" as originally conceptualized by Lamb et al. (1987). Following an overview of data and methods, we present our findings and conclude with a discussion.

\section{Background}

\section{International Evidence on Fathers' Contact and Involvement with Nonresident Children}

International evidence reveals a growing demand from nonresident fathers to spend more time with their children and to engage more actively in parenting. Various studies document that, over the past three decades, there has been a steady rise in the share of fathers who remain in contact with their children after union dissolution (Amato, Meyers, \& Emery, 2009; Nielsen, 2011), and a substantial increase in the proportion of divorced parents who voluntarily opt for shared residential and legal custody arrangements. In the US context, fatherhood has traditionally been regarded as part of a package deal (Furstenberg \& Cherlin, 1991; Townsend, 2004) in which fulfillment of fatherhood roles is largely contingent on the relationship between the father and the child's mother (Tach, Mincy, \& Edin, 2010).

Recent data challenge this package deal hypothesis, as the proportion of nonresident parents who want to maintain close affective bonds with their children and engage in cooperative co-parenting increases (Goldberg, 2015). A study of father-child contact across divorce cohorts in the Netherlands (Westphal, Poortman, \& van der Lippe, 2014) also shows that contact between divorced fathers and their children has increased considerably over the past decades partly due to the upward trend in fathers' participation in childrearing while married. Fathers who were more closely involved with their children prior to separation tend to stay in closer contact with them also after union dissolution (Juby, Le Bourdais, \& Marcil-Gratton, 2005; Westphal et al., 2014).

Based on the existing literature, nonresident fathers' involvement in childrearing and continued father-child interaction after parental separation have a positive impact on children's well-being and life chances-for instance, educational attainment (Amato et al., 2009; Ryan, Kalil, \& Ziol-Guest, 2008). These positive effects are largely contingent on the quantity and quality of the 
time shared, and on the level of fathers' engagement in child-rearing decisions (Amato \& Fowler, 2002; Bernardi, Härkönen, \& Boertien, 2013). Numerous studies have also documented that child visitation, father-child contact, and overnight stays tend to be higher, after separation, for nonresident parents with a higher socioeconomic status (SES) (Grätz, 2017). In line with the above, Kalmijn (2015) reported a higher level of involvement of nonresident parents in high-SES families than in low SES-families in Germany, the United Kingdom, Sweden, and the Netherlands. Since children's loss of contact with their father is more common in disadvantaged strata, existing social differences in the rate of family disruption and in the relationships of fathers and children who live apart tend to exacerbate gender and social inequalities.

In Latin America, these issues have not received the same attention as in developed countries, partly because of the scarcity of adequate data. With some exceptions (e.g. Bucheli, 2003; Budowski \& Rosero-Bixby, 2003; Cuesta \& Meyer, 2014; Ishida, 2010), there are few studies on the level of contact and financial transfers from nonresident parents to children in Latin American countries. This is highly problematic, as children born outside marriage currently outnumber those born within marriage in the region (CastroMartín, Cortina, Martín-García, \& Pardo, 2011). The majority of nonmarital births are born within consensual unions, which have a higher probability of dissolution than formal marriages. There is also an increasing number of children born to women with no coresident partner-the proportion is estimated to have grown from 7 percent in 1970 to 15 percent in 2000 in the region (Laplante, Castro-Martín, Cortina, \& Martín-García, 2015).

The historically high prevalence of cohabitation and its more recent rise (Esteve \& Lesthaeghe, 2016) have contributed to high and rising levels of union disruption (Cerruti \& Binstock, 2009; Ullmann, Maldonado, \& Rico, 2014). As a result, the proportion of families headed by women has become even more widespread over the past decades, and an increasing proportion of children are growing up in father-absent households, which are disproportionally poor (García \& de Oliveira, 2011). Cuesta and Meyer's study (2014) shows, for instance, that less than one-third of custodial-mother families in Colombia receive child support, although it has been amply demonstrated that these transfers could help these families to move out of poverty or get closer to the poverty line.

Despite its high policy relevance to the region, there is very limited knowledge on the magnitude and consequences of father absence from the household as experienced by children, as well as on the factors that predispose nonresidential fathers to fulfill their paternal role from a distance. Although there is a growing interest in men's participation as fathers in Latin America 
(Barker \& Verani, 2008), there is scarce quantitative evidence of the effects of separation on father-child contact and economic transfers due to the paucity of longitudinal data. In this paper, we focus on Uruguay, which provides a relevant case study, since the country has a high level of conjugal disruptions, and child support and father-child contact after parental separation is well below what may be desirable (Cabella, 1998, 2009).

\section{Fathers' Contact and Involvement with Nonresident Children in Uruguay}

Uruguay was the first Latin American country to pass a divorce law (1907), but divorce rates increased markedly only after the 1990s, when separations from cohabiting couples grew considerably as well (Cabella, 2009). These trends imply that an increasing proportion of children are growing in fatherabsent households. According to the last 2011 Census, 36 percent of children aged under 18 years lived with only one of their biological parents (Cabella, Fernández Soto, \& Prieto, 2015). Although the culture of fatherhood has changed in recent decades, the proportion of nonresident fathers who do not pay child support remains remarkably high and shows few signs of waning. In 2001, 58 percent of separated or divorced men did not make financial transfers to their children under 22 years, as shown by a survey on family life in 2001 (Encuesta de Situaciones Familiares [ESF]) . ${ }^{2}$ In 2008, in the second wave of the same survey, the proportion remained virtually unchanged (56\%). Another survey conducted in 2004, Encuesta de Género y Generaciones, led to very similar findings: according to mothers' reports, 56 percent of nonresident fathers did not pay child support. ${ }^{3}$

According to the first wave of the survey used in this study (ENDIS, 2015), nearly half of all fathers (48\%) who did not co-reside with their children under the age of four, did not provide child support payments (Bucheli \& Vigorito, 2015). Low-income fathers were also more reluctant to pay child support. Furthermore, the more conflictive the relationship with the ex-wife/ partner, the less likely a father was to transfer economic resources to his child(ren) after union breakup. Fathers' self-employment was also found to be a significant predictor of noncompliance with child support payment. On the other hand, the type of union (marriage or cohabitation) was not found to influence the provision of economic transfers to children after separation (Bucheli \& Vigorito, 2015).

Children's loss of contact or infrequent interaction with their fathers after parental rupture is habitual. According to ENDIS Wave 1, in 2013 half of the children under four years of age who did not coreside with their father had at least weekly face-to-face contact, but nearly one-third (32\%) did not 
maintain any contact. Fathers of higher social strata were more prone to maintain frequent contact with their offspring after separation or divorce (Bucheli \& Vigorito, 2015). As in many other countries, the "tale of two fathers" (Livingstone \& Parker, 2011) is becoming salient in Uruguay. On the one hand, there is a growing proportion of co-resident and nonresident fathers heavily involved with their children and, on the other hand, a significant portion of fathers (about one-third) who completely lose contact with their children after union breakdown.

Previous research has shown that the larger the parent's involvement in child-rearing, the more important the continuity of contact after separation becomes for the child's well-being (Poortmaan, 2018). The consequences of increased family instability on children's well-being and family life, as well as differentials in nonresident father involvement by social strata, are poorly studied in Uruguay. However, this issue is particularly relevant insofar as the increasing rates of union rupture, coupled with the poor implementation of policies aimed at supporting families after disruption, may intensify existing social inequalities.

\section{Research Questions}

Frequent father-child contact after union dissolution is assumed to be in children's best interests, but parental separation generally entails the weakening of father-child interactions due to the so-called parental loss and instability perspectives (Poortman, 2018). The parental loss perspective assumes losses for children in social and economic resources after separation because children often lose contact with the nonresident parent. The instability perspective entails that parents and children need to adjust to new family roles and interactions after separation. Nevertheless, the literature has documented that there is considerable heterogeneity in post-separation father-child ties and the causes of such heterogeneity are not consistent (Grätz, 2017; Kalmijn, 2015). In many cases, the parent who leaves the household after separationmost often the father - reduces or even loses contact with his child(ren), but in other cases, they remain fully involved in their child's life.

Drawing on these arguments about the effect of parental loss and stress associated to the turmoil and instability of the first few years after separation, prior research has shown that negative impacts on children's well-being tend to lessen when post-separation parenting arrangements mirror pre-separation ones (Poortman 2018). In this study, we contribute to this research area by providing a novel analysis of the relationship between pre-separation fathering practices and post-separation child-father involvement in Uruguay. Specifically, we examine whether nonresident father-child interactions differ according to 
the degree of father's involvement in child-rearing prior to separation. Recent empirical evidence has found a positive association between fathers' prenatal involvement and later levels of care engagement (Cabrera, Fagan, \& Farrie, 2008; Habib, 2012). We believe that, from a life course perspective, being involved in early childhood helps men develop a closer relationship with the child, which may strengthen their commitment and engagement over time, even in the event of conjugal separation.

A man for whom fatherhood plays an important part of his male identity will probably show greater motivation for the changes and adaptations needed to care for the child after union dissolution. For this type of men, the father identity is not embedded in the package deal formula, since they do not view fatherhood as closely dependent on the conjugal relationship. Despite the eventual breakup of the couple, these men do not detach themselves from the father role and feel obliged to actively participate in their child(ren)'s life (Habib, 2012). Fathers' commitment and ties with their child(ren) during conjugal union increase their preferences for greater paternal involvement and therefore can have long-reaching effects. It is therefore expected that fathers with stronger bonds with their offspring will most likely desire to stay involved throughout the child(ren)'s life course. Indeed, it has been shown that differences in the subjective centrality that the nurturing role acquires for fathers may explain variations with regard to actual involvement (González, Lapuerta, Martín-García, \& Seiz, 2018; Rane \& McBride, 2000). Consequently, our initial hypothesis is as follows:

Hypothesis 1: Although union breakup usually leads to a decline in father-child interaction, more engaged fathers before separation (in terms of total time investments in child-rearing) are expected to be also more involved in raising their children after union breakup. (H1)

A common view in the literature is the traditionalization of gender roles occurring worldwide during family formation (Grunow \& Evertsson, 2016). It is a well-stylized fact that while women usually devote more time to routine household chores than men, the gap widens considerably when small children are present. Moreover, the largest gender inequalities are found in childcare. Fathers spend less time than mothers with children, and perform more leisure activities (Craig, 2006; Miller \& Nash, 2017). Even though paternal involvement in childcare can be measured in multiple ways, it is the amount of time shared - be it in absolute or relative levels of involvement in child-rearing - which is most often used, yet we consider it is not enough, in itself, to fully analyze the involvement of men in care activities. 
Lamb, Pleck, Charnow, and Levine (1987) theorize three main components of what has been labeled as "positive paternal involvement" which allow us to explore more diverse and complex aspects of fathers' involvement in childcare, namely: (i) engagement, which refers to the time dedicated to care, play, or leisure; (ii) accessibility, understood as the time availability or flexibility to be with the child and respond to his/her needs; and (iii) responsibility, which involves making daily decisions and monitoring care tasks (e.g., deciding meals, taking care of the backpack, arranging and attending medical appointments, determining when the child needs new clothes, etc.). This latter ability to take initiative and organize is particularly distinctive of an active fatherhood, as many fathers are mere executors of instructions and explicit directions without being as attentive as mothers to what needs to be done (Craig, 2006).

As a result, paternal involvement may not only differ in terms of total time investment but also with regard to the dimensions of care in which men engage. In fact, prior empirical evidence suggests that it is not so much the amount of time per se what matters for the father-child relationship, but rather the extent to which men are transforming their identities and practices as fathers (González et al., 2018). Thereby, we would like to explore whether the adoption of fathering practices covering these three dimensions before separation encourages post-separation paternal involvement.

We expect differences in the development of an engaged, accessible and responsible type of fatherhood during the union will explain variations in subsequent paternal involvement after union dissolution. More specifically, our second hypothesis can be formulated as follows:

Hypothesis 2: We expect men who embraced a responsible father involvement before separation to be also more involved in their children's lives after separation. (H2)

In other words, in couples with a more traditional gendered division of care practices where fathers only interact with the child in the form of play or leisure and/or were barely accessible to respond to the child's needs, assuming a secondary role compared to the mothers' regarding responsibility, the post-separation paternal involvement will be lower.

This hypothesis is clearly innovative and entails a new insight into the driving forces of post-separation fathers' involvement (Haux, Platt, \& Rosenberg, 2015) since, to the best of our knowledge, no study has been undertaken to quantitatively investigate the extent to which fathers' active involvement in child-rearing is relevant to explain post-separation fatherchild contact and economic support in the Latin American region. This seems to be a particularly pertinent issue to explore, as earlier research has noted the 
importance of this type of paternal involvement for both children's cognitive and socio-emotional abilities and gender equity across Western societies (Cano, Perales, \& Baxter, 2018; Deutsch, Servis, \& Payne, 2001; Pleck, 2010) and Latin America (Barker \& Verani, 2008).

\section{Analytical Sample and Methodology}

High costs make longitudinal databases rare in Latin America, but this study benefits from an ongoing longitudinal survey on early childhood, the Encuesta de Nutrición, Desarrollo Infantil y Salud [ENDIS] - National Survey on Early Childhood Health, Nutrition, and Development. This survey is being carried out by academic and government institutions and headed by the National Statistics Institute of Uruguay. So far, the survey comprises two waves. The first one was collected in 2013 and consisted of a sample of 3,077 children aged 0 to 3 years. In 2016, the second wave collected data from 2,455 children aged 3 to 6 years (sample attrition was 20.2\%).

This data source meets two crucial requirements. First, 76.7 percent of the sampled children were living with both parents in Wave 1. Three years later, in the second wave, 177 of them $(7.5 \%)$ had ceased to live with their fathers due to union breakup between waves, generating the focal subsample for this study. ${ }^{4}$ Second, the ENDIS database allows us to measure fathers' involvement both pre- and post-separation. Data in Wave 1 describe fathers' and mothers' involvement in several home tasks in detail (cooking, buying groceries, housekeeping, paying the bills, changing diapers, feeding the children, scolding children when they misbehave, taking them to the doctor, playing with them, etc.) and measures the amount of time fathers spend on childcare. Wave 2 focuses intensely on nonresident father-child involvement: at least 15 survey questions refer to frequency and intensity of contact between father and child, parental attitudes, and economic and noneconomic support.

The information collected allows the assessment of three dimensions of father-child involvement after separation: visiting patterns (frequency of inperson contact), financial contributions to child maintenance (regular child support payments), and participation in child-rearing decisions in several areas (education, health, habits, and discipline). It is important to note that the analysis relies upon resident mothers' reports about paternal involvement after separation because ENDIS does not follow the parent leaving the household. This requires some caution since reports from a single informant (the mother) might be somewhat biased, that is, mothers more often report higher pre-separation and post-separation parental conflict and lower father involvement (Poortman, 2018), leading to an underestimation of father involvement before and after union dissolution. 
The main focus of the analysis is on two key dimensions of father involvement before separation: fathers' absolute time devoted to child-rearing and the extent to which fathers develop an engaged, accessible, and responsible type of fatherhood in Wave 1. The first dimension, fathers' absolute time devoted to child-rearing, is a covariate which indicates the total number of hours per week spent by the father in childcare activities. ${ }^{5}$ We distinguish between fathers who dedicated no time at all to childcare when they were partnered (no involvement) ${ }^{6}$, fathers who spent up to 39 hours (low involvement), and fathers who dedicated 40 or more hours (high involvement). This measure of pre-separation involvement ranks fathers into thirds according to the number of hours devoted to childcare: fathers with no involvement (31.1\%), low involvement (33.5\%), and high involvement (35.3\%), respectively. The number of hours reportedly devoted to childcare by fathers is noticeably greater than those recorded in the 2013 Uruguayan Time Use Survey (Batthyány, 2015). However, since they are largely based on mothers' reports (in Wave 1, respondents could be either the mother or the father of the focus child, but 96.6 percent of questionnaires were responded by the mother), it is difficult to argue that they are subject to substantial overreporting. It is possible that, since enrollment in early childhood education is low in Uruguay (Santiago, Ávalos, Burns, Morduchowicz, \& Radinger, 2016) and many children under 3 years are cared for at home, mothers' reports include fathers' time devoted to "secondary" or "passive" childcare. Nonetheless, by ranking fathers into three broad groups of similar size according to the total time devoted to childcare, we expect to minimize potential biases.

With regard to the second dimension of fathers' involvement, mothers indicated whether co-resident fathers participated in the following child-rearing tasks: "playing and/or outings with child," "scolding children when they misbehave," "transport to various places," "changing diapers," "washing child, bathing" "putting child to bed," "cooking/feeding the child," and "taking children to the doctor." 7 We take some of these tasks as proxies for the three dimensions of care in which men engage to test whether an active fatherhood before separation is conducive to a greater post-separation paternal involvement. We distinguish father engagement in care only in the form of play or leisure (playing with the child), father accessibility to respond to the child's needs (cooking/feeding the child), and father responsibility to make and monitor care tasks (attending medical appointments with the child).

We also include a small number of control variables which have been shown to influence father's involvement after separation (Westphal et al., 2014). Father's educational attainment indicates whether the father was enrolled in school for at least 9 years $^{8}$ and we take it as a proxy for socioeconomic status. Higher educated fathers may be inclined to remain involved 
after separation due to more modern and egalitarian parenting styles. A control variable for child's gender is also included in the analysis. Previous studies on the effects of parental separation on paternal involvement by child gender and age have shown a higher involvement of separated fathers in their sons' lives than in their daughters' (Kalmijn, 2015) as well as with younger children (Skevik, 2006). We did not include a control for child's age due to low variability: because of design characteristics, children's ages were less than 4 years at Wave 1 and 4 to 6 at Wave 2 .

We first perform a descriptive analysis to depict fathers' degree of involvement with their children after separation, looking at three key dimensions: frequency of contact, financial support, and participation in child-rearing decisions (about education, health, habits and discipline). We also examine the association between pre-separation and post-separation fathers' involvement. Next, we conduct a logistic regression analysis to examine this association in a multivariate framework. We have kept the number of covariates in the models to a minimum because of the relatively small size of the analytical sample. ${ }^{9}$

\section{Results}

\section{Descriptive results}

Table 1 shows a wide variation in the patterns of paternal involvement after separation in Uruguay. The frequency of nonresident fathers' face-to-face contact with their child ranges from every day $(16.2 \%)$ to no contact at all (13.3\%), but nearly three-fourths of separated fathers (72.3\%) are in touch with their child at least once a week. It should be noted that in our analytical sample all children are under 6 years of age and union breakdown is relatively recent (in the past 3 years), which is likely to favorably affect the frequency of father-child interaction, although it is foreseeable that it will diminish over time (Albertini \& Garriga, 2011). With regard to nonresident fathers' fulfillment of their economic responsibilities, the picture looks mixed: 53.6 percent pay child support regularly, 9.9 percent do so occasionally, and 36.5 percent not at all. Moreover, nonresident fathers' involvement on child-rearing decisions is undeniably low: less than 15 percent of them participate on decisions concerning education, health, habits and discipline, whereas the corresponding figures for resident fathers range from 51 percent in health-related decisions to 62 percent in educational decisions. Generally speaking, the broad variation in the observed patterns of nonresident fathers' involvement with their children suggests that social norms on paternal responsibilities become weaker after separation and that family obligations are frequently misperceived as optional for men (Miller, 2011). 
Table I. Selected Indicators of Parental Involvement.

\begin{tabular}{|c|c|c|}
\hline & Nonresident Fathers & Resident Fathers \\
\hline & $\%$ & $\%$ \\
\hline \multicolumn{3}{|l|}{ Face-to-face contact } \\
\hline Every day & 16.2 & \\
\hline $5-6$ days per week & 7.4 & \\
\hline 3-4 days per week & 20.0 & \\
\hline $\mathrm{I}-2$ days per week & 28.7 & \\
\hline Once per 15 days & 8.5 & \\
\hline Once a month & 2.6 & \\
\hline Some times per year & 3.2 & \\
\hline No contact & 13.3 & \\
\hline \multicolumn{3}{|l|}{ Economic support } \\
\hline Yes, regularly & 53.6 & \\
\hline Yes, occasionally & 9.9 & \\
\hline No & 36.6 & \\
\hline \multicolumn{3}{|c|}{ Participation in child-rearing decisions } \\
\hline Education & 14.6 & 61.5 \\
\hline Health & 8.9 & 51.3 \\
\hline Habits & 13.3 & 58.4 \\
\hline Discipline & 13.1 & 60.9 \\
\hline$N$ & 177 & 2378 \\
\hline
\end{tabular}

Source: ENDIS (Wave 2).

As noted above, in order to examine whether there is certain continuity in father's roles before and after separation, we have classified nonresident fathers in three groups according to the amount of hours spent in childcare work while they were still married or cohabiting. The pattern observed is that fathers' involvement in childcare before separation is higher among those with higher educational attainment. Specifically, fathers with more than 9 years of schooling devoted to childcare activities seven more hours a week than their less educated counterparts. Pre-separation father's higher involvement obviously entails a more egalitarian division of labor. Nonetheless, fathers do not participate uniformly in all childcare-related activities. As shown in Figure 1, their rate of participation is greater in ludic activities, such as engaging in child play, than in routine childcare activities, such as changing diapers, or in activities associated with the responsibility dimension of parental care, such as taking the child to a medical appointment. 


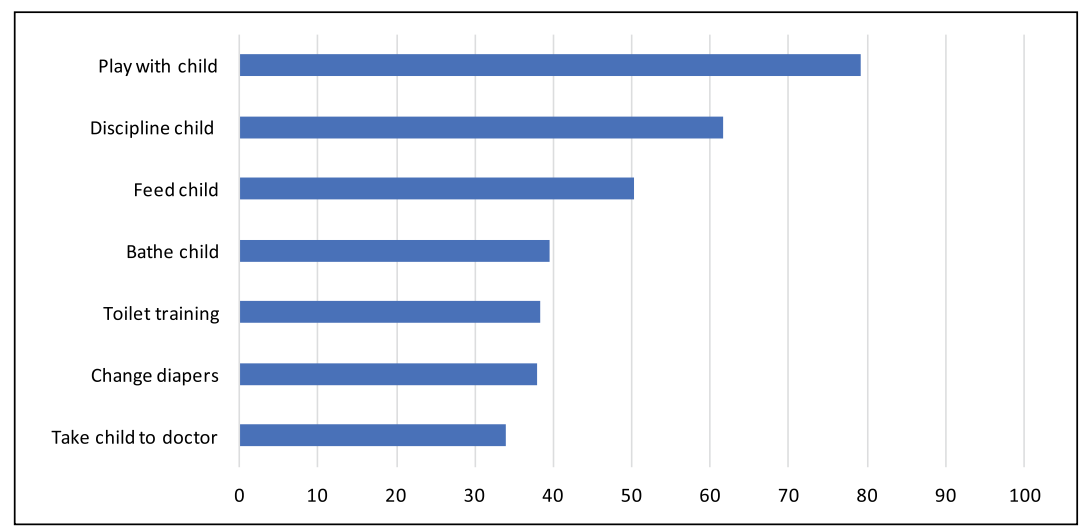

Figure I. Fathers' Pre-separation Involvement: Percentage of Fathers Involved in Selected Parenting Tasks

Source: ENDIS (Wave I).

In order to examine whether fathers' engagement in childcare while partnered has some bearing on their parental commitment after union breakup, we cross-tabulated our measure of pre-separation involvement (from Wave 1) with three dimensions of post-separation involvement: frequency of face-toface contact, financial support, and participation in decisions concerning child's education (from Wave 2). Table 2 reveals an evident association between pre-separation and post-separation fathers' involvement. Only about one-third of fathers who had little to no involvement in childcare activities while partnered see their children three or more times a week after separation. In contrast, two-thirds of fathers classified as highly involved before separation have a frequency of contact of three or more times a week after separation. The association is also noticeable, although not strictly linear, with regard to child support: whereas only 42 percent of fathers with no pre-separation involvement provide regular child support payments, this percentage rises to 58 percent and 54 percent among fathers with low and high pre-separation involvement respectively. Although we have already noted that participation of nonresident fathers in decisions related to child-rearing is generally low, nonresident fathers who were highly involved in childcare before separation seem to participate to a greater extent in decisions concerning their child's education.

The three dimensions of post-separation paternal involvement examined are strongly correlated. For instance, 64 percent of nonresidential fathers having contact with their child three or more times per week pay child support 
Table 2. Association between Pre-separation and Post-separation Father's Involvement with Child.

\begin{tabular}{|c|c|c|c|}
\hline \multirow{3}{*}{$\begin{array}{l}\text { Pre-separation } \\
\text { Involvement }\end{array}$} & \multicolumn{3}{|c|}{ Post-separation Involvement } \\
\hline & $\begin{array}{c}\text { Frequency of } \\
\text { Contact }\end{array}$ & $\begin{array}{c}\text { Child } \\
\text { Support }\end{array}$ & $\begin{array}{l}\text { Participation } \\
\text { in Decisions }\end{array}$ \\
\hline & $3+$ times a week & Regular & Education \\
\hline None & 34.3 & 41.9 & 16.7 \\
\hline Low & 37.5 & 58.2 & 7.9 \\
\hline High & 66.2 & 54.0 & 19.0 \\
\hline Total & 47.0 & 52.3 & 14.3 \\
\hline $\mathrm{N}$ & 167 & 167 & 167 \\
\hline
\end{tabular}

Source: ENDIS (Wave I and 2).

regularly, compared to 49 percent of those who have a lower frequency of contact. ${ }^{10}$ Similarly, 26 percent of nonresident fathers who pay child support regularly participate in decisions related to their child's education, compared to 10 percent of those who do not make economic contributions to child maintenance.

\section{Multivariate Analysis}

Next, we will examine, in a multivariate framework, whether paternal involvement before and after union breakup are positively related. Preceding studies have shown numerous factors affecting fathers' involvement with their child(ren) after separation. Given the small size of our analytical sample, we have included in the models only a few of these factors as controls. Table 3 presents the adjusted odds ratios from logit models for the probability of nonresidential fathers having a high frequency of contact with their child, paying child support on a regular basis, and participating in decisions about their child's education.

According to the models presented, pre-separation involvement is the only factor under consideration which has a statistically significant impact on postseparation frequency of contact with the child. Specifically, fathers who were highly engaged in childcare while partnered are nearly four times more likely to see their child often (three or more times a week) after separation than fathers who did not participate in childcare before separation. Although the proxy for fathers' socioeconomic status - educational attainment - is positively correlated with post-separation paternal contact with the child, once pre-separation 
Table 3. Logistic Regression Models of the Effect of Father's Pre-separation Involvement with Child on Three Dimensions of Post-separation Involvement. Odds Ratios.

\begin{tabular}{|c|c|c|c|}
\hline & $\begin{array}{l}\text { Has contact } \\
\text { with child } 3+ \\
\text { times a week }\end{array}$ & $\begin{array}{l}\text { Pays child } \\
\text { support } \\
\text { regularly }\end{array}$ & $\begin{array}{l}\text { Participates in } \\
\text { decisions about } \\
\text { education }\end{array}$ \\
\hline \multicolumn{4}{|c|}{ Pre-separation involvement (total hours of childcare) } \\
\hline None & I & 1 & I \\
\hline Low & 1.16 & 1.30 & $0.23 * *$ \\
\hline High & $3.99 * * *$ & 1.26 & 0.88 \\
\hline \multicolumn{4}{|c|}{ Father's engagement (played with the child) } \\
\hline No & 1 & 1 & I \\
\hline Yes & 0.64 & 0.70 & 0.62 \\
\hline \multicolumn{4}{|c|}{ Father's accessibility (cooked for the child) } \\
\hline No & 1 & 1 & I \\
\hline Yes & 0.80 & 1.53 & 1.51 \\
\hline \multicolumn{4}{|c|}{ Father's responsibility (took child to doctor) } \\
\hline No & 1 & 1 & I \\
\hline Yes & 1.04 & $2.50 * *$ & 2.11 \\
\hline \multicolumn{4}{|c|}{ Father's educational attainment } \\
\hline 9 years or less & 1 & 1 & I \\
\hline$>9$ years & 1.34 & $3.04 * * *$ & $3.14 * *$ \\
\hline \multicolumn{4}{|l|}{ Child gender } \\
\hline Female & 1 & I & I \\
\hline Male & 1.16 & 0.81 & $0.29 * *$ \\
\hline$N$ & 177 & 172 & 177 \\
\hline $\begin{array}{l}\text { Log } \\
\text { pseudolikelihood }\end{array}$ & -8137.72 & -7650.900 & -4637.25 \\
\hline Pseudo R2 & 0.092 & 0.111 & 0.143 \\
\hline
\end{tabular}

$* * p<.05 ; * * * p<.01$.

Source: ENDIS (Wave I and 2).

engagement in childcare is entered in the model, it is no longer statistically significant.

In contrast, the provision of child support is strongly associated to father's social stratification position, indicated by educational attainment. Nonresident fathers with higher educational attainment are three times more likely to contribute regularly to their child maintenance than those with lower education. Educational level is highly correlated with type of employment (formal vs. informal jobs) and earning power; hence, compliance with child support obligations is linked, not only to father's willingness, but also to their capacity to 
pay. Results suggest that, with regard to the financial dimension of post-separation involvement, the father's economic resources are more influential than the degree of pre-separation engagement in childcare, which loses its statistical significance once educational attainment is included in the model. Similarly, father's participation in child's educational decisions after separation is influenced by father's education, but not by amount of time dedicated to childcare before separation. Therefore, $\mathrm{H} 1$ is supported by the data for one dimension of post-separation father-child involvement (frequency of contact), but not for the other two dimensions (child support payment and participation in child-rearing decisions).

With regard to the three dimensions of care previously identified herein, results suggest that father's engagement and accessibility before separation have no statistically significant impact on post-separation frequency of father-child contact and payment of child support. On the other hand, the indicator for father's responsibility to make and monitor care tasks - attending medical appointments with the child - before separation does have a significant impact on father's likelihood to provide regular child support after separation. Contrary to our expectations, fathers' engagement in responsibility tasks before separation does not have a statistically significant effect on their participation in child's educational decisions after separation, although the coefficient is in the predicted direction and almost significant $(p<.10)$. Therefore, $\mathrm{H} 2$ is only partially supported by the data.

\section{Discussion}

There is a growing emphasis on more nurturing fathering and co-parenting practices in parallel to increasing rates of parental breakups, with more fathers living apart from their children. Although the literature is prolific on father-child relationships after separation in high-income countries, empirical research on these issues is scarce in Latin America, partly due to the paucity of adequate data. The present research is aimed at contributing to fill this gap. Our study makes use of an ongoing longitudinal survey on early childhood in Uruguay to shed some light on the patterns and driving forces influencing father-child relationships after union breakup. In particular, we have examined whether fathers more involved before separation maintain greater levels of involvement after separation as well.

Our findings confirm that fathers' pre-separation involvement affects their post-separation parenting behavior, although this association does not reach statistical significance in all aspects of post-separation involvement considered. Those fathers who spent more time caring for and nurturing their child while partnered, also have more frequent interactions with their child after 
separation. Yet, with regard to compliance with child support and participation in child-rearing decisions after separation, fathers' educational level, a conventional proxy for economic resources, is much more influential than the degree of pre-separation engagement in childcare. As concerning the three dimensions of paternal involvement as originally conceptualized by Lamb et al. (1987), our results suggest that active fatherhood before separation, when it involves responsible fathering practices, has a clear positive effect on compliance with child support after separation. Nonetheless, the association is not statistically significant regarding frequency of contact and participation in child-rearing decisions. In brief, the study provides evidence for the links between pre-separation and post-separation fathers' active involvement with their children, but the associations found were not as large as we had expected. It is not possible to discard a type II error due to the relatively small sample size of our study.

Our findings are in line with previous studies but provide a more detailed examination of the different dimensions of pre-separation and post-separation involvement. This study is, to the best of our knowledge, the first nationally representative study to examine the role of pre-separation paternal involvement in terms of the dimensions of care in which men engage. We had argued that it is not only the number of hours per se devoted to care activities what matters, but also the extent to which men adhere to new parenting practices, not only spending time with the child, but engaging in physical and routine care activities, taking on an organizing role in care work, and adapting their time schedule to the needs of the child. For instance, men who arrange and attend medical appointments with the child display availability with a proactive attitude and, more importantly, take responsibility for monitoring what is needed for the child. Our results show that this kind of fathers are indeed more prone to provide financial support in the event of parental breakup.

From a policy point of view, our findings suggest that efforts to encourage fathers' involvement in parenting early in the child's life-for instance, through integration of fathers-to-be in childbirth preparation classes at health centers, nontransferable paternity leave policies, and gender-neutral flex time programs in the workplace - may have payoffs in terms of father-child contact, economic support, and participation in child-rearing decisions, even in the event of parental separation. This is particularly relevant in the current context of increasing conjugal instability and ensuing changes in family organization.

Much of policy development in Latin America around men's roles in families has been aimed at enacting and enforcing child support legislation, now universal in the region. However, the culture of fatherhood has undergone 
considerable changes in recent decades, and fathers are increasingly expected to fulfill both breadwinning and nurturing roles. The norms of post-separation fatherhood have also changed, currently entailing not only economic support, but also participation in child-rearing (Westphal et al., 2014). If we are concerned about children's well-being, we should continue demanding more rigorous enforcement of child support obligations, not only because child support is a key mechanism for alleviating poverty, but also because improvements in child support compliance are likely to strengthen nonresident parents' social bonds with their children. Furthermore, policies should also aim at encouraging shared parenting responsibilities and facilitating fathers' early involvement in childcare, because strong father-child ties are less likely to be disrupted after separation. We should not deny boys and girls the right to enjoy contact and attachment with both parents on an equal basis. Likewise, paternal involvement in early childcare would encourage early socialization in more equal roles, which would contribute to consolidating gender equality. In addition, recent studies point to a positive association between a committed fatherhood and children's greater emotional and cognitive capacity (Pleck, 2010).

Finally, we need to acknowledge some of the limitations of our study. First, the relatively small size of our analytical sample may have precluded the detection of statistically significant effects and our results should be seen as exploratory. It is usually difficult to collect longitudinal data with sufficient number of parents who separate in between waves. Future studies might be able to reduce this problem by pooling data from subsequent waves. They might also be able to enhance data analysis and interpretation by using information on child custody (not available in our data) and better proxy measures for the three dimensions of paternal involvement. Second, as formerly noted, the measures of post-separation fathers' involvement are based on mothers' reports. This is potentially problematic if information about nonresident father's involvement is misreported in ways that are related to prior parenting behavior, since this would bias our estimates. However, we do not expect misreporting to vary systematically with our broad indicators of pre-separation engagement in childcare. Third, our study excludes by design fathers who have never lived with their children. Single motherhood has been historically common in Latin America and has become even more frequent in recent decades (Laplante et al., 2015). In such cases, improvements in paternity establishment would have to be implemented before aiming at fostering involvement of nonresident fathers in their children's lives. Notwithstanding these limitations, this study offers some original insights on the links between pre-separation and post-separation fathering behavior, and reflects on 
strategies to diminish the potentially adverse consequences of father-absent households for children.

\section{Acknowledgments}

We thank the members of the Grupo de Estudios de Familia (Universidad de la República, Uruguay) for their valuable comments.

\section{Declaration of Conflicting Interests}

The author(s) declared no potential conflicts of interest with respect to the research, authorship, and/or publication of this article.

\section{Funding}

The author(s) disclosed receipt of the following financial support for the research, authorship, and/or publication of this article: This research has been supported by the Spanish Ministry of Economy and Competitiveness under projects CSO2013-43483-R (The role of men in family dynamics from an international perspective: www.menrolesproject.com) and CSO2017-89397-R.

\section{ORCID iD}

Ignacio Pardo (iD https://orcid.org/0000-0002-6185-1082

\section{Notes}

1. In this study, we use "separation" to refer to both a separation from a consensual partner and separation or divorce from a married partner.

2. The ESF coverage included the metropolitan area, which represents more than 50 percent of the Uruguayan population.

3. In this survey, men with child(ren) under 22 years living apart from them were also asked whether they paid child support and their reported level of compliance was significantly higher than that of women's reports: around 70 percent declared that they made financial transfers to their children (Bucheli \& Cabella, 2009).

4. We excluded 495 not co-residing fathers $(71,7 \%)$, because they were already not co-residing in Wave 1, therefore providing us with no information on father's pre-separation involvement in childcare. We also excluded from the analysis eight cases of children living primarily with their father after divorce.

5. We replicated the analysis with a different specification of this covariate: the father's relative contribution, vis-à-vis the mother, to childcare. The results (available upon request) did not qualitatively differ from those presented here.

6. They also replied "no" to another question: "Is the father involved in childcare?"

7. The survey question is stated as: "Now I would like to talk about how you and your partner organize your domestic life. How do you distribute tasks with your 
partner in the following areas?" The questionnaire lists several dimensions, as stated above. When the answers are "mostly my partner" or "my partner and me (50/50)" we assume fathers are participating.

8. Compulsory education in Uruguay encompasses 9 school years (primary and lower secondary education).

9. We acknowledge that many other individual and contextual factors, such as fathers' financial resources and type of employment, mothers' education, the quality of the interparental relationship, geographical distance, and both partners' subsequent partnerships and additional children, will shape the patterns of nonresident fathers' level of involvement in their children's lives (Cooksey \& Craig, 1998; Juby, Billette, Laplante, \& Le Bourdais, 2007; Köppen, Kreyenfeld, \& Heike, 2018; Manning, Stewart, \& Smock, 2003). However, the small sample size limits our ability to include a large number of covariates in the models.

10. Fathers with regular contact with their children but not providing economic support $36 \%$ of fathers having contact with their child three or more times per week) are probably sharing their custody. If so, they provide for the child when he/she is staying with them and not via a financial contribution to his/her mother. Unfortunately, we have no data on child custody to check this hypothesis properly.

\section{References}

Albertini, M., \& Garriga, A. (2011). The effect of divorce on parent-child contacts. European Societies, 13(2), 257-278.

Amato, P. R., \& Gilbreth, J. G. (1999). Nonresident fathers and children's well-being: A meta-analysis. Journal of Marriage and Family, 61(3), 557-573.

Amato, P., \& Fowler, F. (2002). Parenting practices, child adjustment and family diversity. Journal of Marriage and Family, 64(3), 703-716.

Amato, P. R., Meyers, C., \& Emery, R. (2009). Changes in nonresident father-child contact from 1976 to 2002. Family Relations, 58(1), 41-53.

Barker, G., \& Verani, F. (2008). Men's participation as fathers in the Latin American and Caribbean region: A critical literature review with policy considerations. Rio de Janeiro: Promundo and Save the Children.

Batthyány, K. (2015). Los tiempos del cuidado en Uruguay. In Batthyány, K. (Coord.), Los Tiempos del Bienestar Social. Género, Trabajo No Remunerado y Cuidados en Uruguay. Montevideo: Doble Clic.

Bernardi, F., Härkönen, J., \& Boertien, D. (2013). Effects of family forms dynamics on children's well-being and life chances: Literature review. Families and Societies Working Papers Series, No. 4. Retrieved from http://www.familiesandsocieties.eu

Bucheli, M. (2003). "Transferencias y visitas entre hijos y padres no corresidentes". In Nuevas Formas de Familia. Montevideo: Udelar-UNICEF.

Bucheli, M., \& Cabella, W. (2009). El incumplimiento en el pago de las pensiones alimenticias, el bienestar de los hogares y el contexto legal vigente en Uruguay. Revista Latinoamericana de Población, 3(4-5), 123-142. 
Bucheli, M., \& Vigorito, A. (2015). Después de la ruptura: efectos de la separación en los contactos entre padres e hijos y en el bienestar de las mujeres. In M. Bucheli, W. Cabella, M. Nathan, P. Fitermann, A. Vigorito, \& M. Zerpa (Eds.), Cambio familiar y bienestar de las mujeres y los niños en Montevideo y área metropolitana (pp. 43-63). Un estudio longitudinal. Montevideo: Udelar, UNICEF.

Budowski, M., \& Rosero-Bixby, L. R. (2003). Fatherless in Costa Rica: Child acknowledgment and support among lone mothers. Journal of Comparative Family Studies, 34(2), 229-254.

Cabella, W. (1998). La evolución del divorcio en Uruguay (1950-1995). Notas de Población, 26(67/68), 209-246.

Cabella, W. (2009). Dos décadas de transformaciones de la nupcialidad uruguaya. La convergencia hacia la segunda transición demográfica. Estudios Demográficos y Urbanos, 24(2), 389-427.

Cabella, W., Fernández Soto, M., \& Prieto, V. (2015). Las transformaciones de los hogares uruguayos vistas a través de los censos de 1996 y 2011. In J. J. Calvo (Coord.), Atlas Sociodemográfico y de la Desigualdad del Uruguay, Fascículo 6. Montevideo: Trilce.

Cabrera, N., Fagan, J., \& Farrie, D. (2008). Explaining the long reach of fathers' prenatal involvement on later paternal engagement. Journal of Marriage and Family, 70, 1094-1107.

Cano, T., Perales, F., \& Baxter, J. (2018). A matter of time: Father involvement and child cognitive outcomes. Journal of Marriage and Family (early view). Retrieved from https://doi.org/10.1111/jomf.12532

Castro-Martín, T., Cortina, C., Martín-García, T., \& Pardo, I. (2011). Maternidad sin matrimonio en América Latina: Un análisis comparativo a partir de datos censales. Notas de Población, 93, 37-76.

Cerruti, M., \& Binstock, G. (2009). Familias latinoamericanas en transformación: Desafios y demandas para la acción pública, Serie Políticas Sociales No. 147, Santiago de Chile: CEPAL.

Choi, J.-K., Palmer, R. J., \& Pyun, H.-S. (2014). Three measures of non-resident fathers' involvement, maternal parenting and child development in low-income singlemother families. Child \& Family Social Work, 19, 282-291. doi:10.1111/cfs.12000

Cooksey, E. C., \& Craig, P. H. (1998). Parenting from a distance: The effects of paternal characteristics on contact between nonresidential fathers and their children. Demography, 35(2), 187-200.

Craig, L. (2006). Does father care mean father share? A comparison of how mothers and fathers in intact families spend time with children. Gender \& Society, 20(2), 259-281.

Cuesta, L., \& Meyer, D. R. (2014). The role of child support in the economic wellbeing of custodial-mother families in less developed countries: The case of Colombia. International Journal of Law, Policy and the Family, 28(1), 60-76.

Deutsch, F. M., Servis, L. J., \& Payne, J. D. (2001). Paternal participation in childcare and its effects on children's self-esteem and attitudes towards gendered roles. Journal of Family Issues, 22(8), 1000-1024. 
ENDIS 2013. (2015). Salud, nutrición y desarrollo en la primera infancia en Uruguay: primeros resultados de la ENDIS, UCC, Mides, Montevideo. Retrieved from http://www.ine.gub.uy/c/document_library/get_file?uuid=25fc124a-d876-4040 -b784-3b25a850b1 fa\&groupId=10181

Esteve, A., \& Lesthaeghe, R. (Eds.). (2016). Cohabitation and marriage in the Americas: Geo-historical legacies and new trends. Cham, Switzerland: Springer International.

Furstenberg, F. F., \& Cherlin, A. J. (1991). Divided families: What happens to children when parents part. Cambridge, MA: Harvard University Press.

García, B., \& de Oliveira, O. (2011). Family changes and public policies in Latin America. Annual Review of Sociology, 37, 593-611. doi:10.1146/annurevsoc-081309-150205

Goldberg, J. S. (2015). Coparenting and nonresident fathers' monetary contributions to their children. Journal of Marriage and Family, 77(3), 612-627. doi:10.1111/ jomf. 12191

González, M. J., Lapuerta, I., Martín-García, T., \& Seiz, M. (2018). Anticipating and practicing fatherhood in Spain. In R. Musumeci \& A. Santero (Eds.), Fathers, childcare and work: Cultures, practices and policies (pp. 17-44). Bradford: Emerald Publishing.

Grätz, M. (2017). Does separation really lead fathers and mothers to be less involved in their children's lives? European Sociological Review, 33(4), 551-562.

Grunow, D., \& Evertsson, M. (2016). Couples' Transitions to Parenthood: Analyzing Gender and Work in Europe. Cheltenham: Edward Elgar.

Habib, C. (2012). The transition to fatherhood: A literature review exploring paternal involvement with identity theory. Journal of Family Studies, 18(2-3), 4-21.

Härkönen, J., Bernardi, F., \& Boertien, D. (2017). Family dynamics and child outcomes: An overview of research and open questions. European Journal of Population, 33(2), 163-184.

Haux, T., Platt, L., \& Rosenberg, R. (2015). Parenting and post-separation contact: What are the links? CASE Working Paper No. 189. London: LSE.

Henz, U. (2014). Long-term trends of men's co-residence with children in England and Wales. Demographic Research, 30(23), 671-702.

Ishida, K. (2010). The role of ethnicity in father absence and children's school enrollment in Guatemala. Population Research and Policy Review, 29, 569-591. doi:10.1007/s11113-009-9160-7

Juby, H., Le Bourdais, C., \& Marcil-Gratton, N. (2005). Sharing roles, sharing custody? Couples' characteristics and children's living arrangements at separation. Journal of Marriage and Family, 67, 157-172.

Juby, H., Billette, J.-M., Laplante, B., \& Le Bourdais, C. (2007). Nonresident fathers and children. Parents' new unions and frequency of contact. Journal of Family Issues, 28(9), 1220-1245.

Kalmijn, M. (2015). Father-child relationships after divorce in four European countries: Patterns and determinants. Comparative Population Studies, 40(3), 251-276. 
Köppen, K., Kreyenfeld, M., \& Heike, T. (2018). Loose ties? Determinants of fatherchild contact after separation in Germany. Journal of Marriage and Family, 80(5), 1163-1175.

Lamb, M. E., Pleck, J. H., Charnow, E. L., \& Levine, J. A. (1987). A biosocial perspective on paternal behavior and involvement. In J. B. Lancaster, J. Altman, A. Rosi, \& L. R. Sherrod (Eds.), Parenting across the Lifespan: Biosocial perspectives (pp. 11-42). New York, NY: Academic Press.

Laplante, B., Castro-Martín, T., Cortina, C., \& Martín-García, T. (2015). Childbearing within marriage and consensual union in Latin America, 1980-2010. Population and Development Review, 41(1), 85-108.

Livingston, G., \& Parker, K. (2011). A tale of two fathers. More are active, but more are absent. Pew Social \& Demographic Trends. Washington, DC: Pew Research Center.

Machin, A. J. (2015). Mind the gap: The expectation and reality of involved fatherhood. Fathering, 13(1), 36-59.

Manning, W. D., \& Smock, P. J. (1999). New families and nonresident father-child visitation. Social Forces, 78(1), 87-116.

Manning, W. D., Stewart, S. D., \& Smock, P. J. (2003). The complexity of fathers' parenting responsibilities and involvement with nonresident children. Journal of Family Issues, 24(5), 645-667.

McLanahan, S., \& Percheski, C. (2008). Family structure and the reproduction of inequalities. Annual Review of Sociology, 34, 257-276.

Miller, T. (2011). Falling back into gender? Men's narratives and practices around first-time fatherhood. Sociology, 45(6), 1094-1109.

Miller, T., \& Nash, M. (2017). "I just think something like the 'Bubs and Pubs' class is what men should be having": Paternal subjectivities and preparing for firsttime fatherhood in Australia and the United Kingdom. Journal of Sociology, 53(3), 541-556.

Nielsen, L. (2011). Shared parenting after divorce. Journal of Divorce \& Remarriage, 52, 586-609.

Pleck, J. H. (2010). Paternal involvement: Revisited conceptualization and theoretical linkages with child outcomes. In M. Lamb (Ed.), The role of the father in child development (5th ed., pp. 67-107). London: John Wiley \& Sons.

Poortman, A. R. (2018). Postdivorce parent-child contact and child well-being: The importance of predivorce parental involvement. Journal of Marriage and Family, $80(3), 671-683$.

Rane, T. R., \& McBride, B. A. (2000). Identity theory as a guide to understanding fathers' involvement with their children. Journal of Family Issues, 21(3), 347-366.

Ryan, R. M., Kalil, A., \& Ziol-Guest, K. M. (2008). Longitudinal patterns of nonresident fathers' involvement: The role of resources and relations. Journal of Marriage and Family, 70(4), 962-977.

Santiago, P., Ávalos, B., Burns, T., Morduchowicz, A., \& Radinger, T. (2016). OECD Reviews of School Resources: Uruguay 2016. Paris: OECD. Retrieved from http://dx.doi.org/10.1787/9789264265530-en 
Seltzer, J. A. (1991). Relationships between fathers and children who live apart: The father's role after separation. Journal of Marriage and Family, 53(1), 79-101.

Seltzer, J. A., \& Bianchi, S. M. (1988). Children's contact with absent parents. Journal of Marriage and Family, 50(3), 663-667.

Sigle-Rushton, W., \& McLanahan, S. (2004). Father absence and child well-being: A critical review. In D. P. Moynihan, T. A. Smeeding, \& L. Rainwater (Eds.), The future of the family (pp. 116-159). New York: Russel Sage Foundation.

Skevik, A. (2006). "Absent fathers" or "reorganized" families? Variations in fatherchild contact after parental break-up in Norway. European Sociological Review, 54(1), 114-132.

Tach, L., Mincy, R., \& Edin, K. (2010). Parenting as a "package deal": Relationships, fertility, and nonresident father involvement among unmarried parents. Demography, 47(1), 181-204. doi:10.1353/dem.0.0096

Townsend, N. W. (2004). The package deal: marriage, work, and fatherhood in men's lives. Philadelphia, PA: Temple University Press.

Ullmann, H., Maldonado, C., \& Rico, M. N. (2014). La evolución de las estructuras familiares en América Latina, 1990-2010: los retos de la pobreza, la vulnerabilidad y el cuidado. Serie Políticas Sociales, N¹93 (LC/L.3819). Santiago de Chile: Comisión Económica para América Latina y el Caribe (CEPAL).

Westphal, S. K., Poortman, A.-R., \& van der Lippe, T. (2014). Non-resident fatherchild contact across divorce cohorts: The role of father involvement during marriage. European Sociological Review, 30(4), 444-456. 